\title{
Paclobutrazol-induced Drought Tolerance in Containerized English and Evergreen Oak
}

\author{
Glynn C. Percival and Ali Mohammed Salim AlBalushi
}

\begin{abstract}
The influence of paclobutrazol (PBZ) applied as a foliar spray and root drench on drought tolerance and recovery from drought, of containerized English and evergreen oak was investigated. PBZ treatment induced a suite of physiological adaptations that would allow both species to tolerate drought; more specifically, increased total leaf content of carotenoids (lutein: $\beta$-carotene:neoxanthin: $\alpha$-carotene) and xanthophylls (zeaxanthin:antheraxanthin:violaxanthin), chlorophylls, proline, superoxide dismutase, and catalase. In addition, PBZ strengthened leaf membrane integrity and increased leaf photosynthetic efficiency and light-induced $\mathrm{CO}_{2}$ fixation before and at the cessation of the drought treatment. Irrespective of species, recovery rates of droughted trees treated with PBZ were 20\% to 50\% higher than non-PBZ-treated trees. In all cases, control trees (non-PBZ-treated) had the least capacity for recovery. Application of some of the PBZ treatments induced overregulation of newly emerged leaves. Results of this investigation indicate applications of the growth inhibitor PBZ either as a foliar spray or root drench induce a suite of physiological adaptations that confer a useful degree of drought tolerance and aid in the recovery from drought-induced damage. It is suggested that PBZ-induced protection of both English and evergreen oak from damage caused by drought stress is mediated by increased antioxidant enzyme and pigment activities.
\end{abstract}

Key Words. Carotenoids; chlorophyll fluorescence; chlorophylls; electrolyte leakage; growth inhibitor; proline; $Q$. Ilex; Quercus robur; stress enzymes; transplanting.

The establishment of trees after planting in urban environments is difficult because of the harsh environmental conditions that exist. These include soil compaction caused by road surfacing, machinery, and pedestrians (Craul 1994); air and soil pollutants (oxides of $\mathrm{S}$ and $\mathrm{N}, \mathrm{SO}_{2}$, polychlorinated biphenyls); heavy metals ( $\mathrm{Zn}, \mathrm{Cu}, \mathrm{Cd})$; atmospheric particulates; ozone; ethylene; deicing salts; and water stress (drought, waterlogging). Such stresses contribute to tree decline through reduced translocation of photosynthates to roots, impaired stomatal function, premature leaf senescence, clogged lenticels, branch dieback, stem/trunk lesions, leaf scorch, tip burn of conifers, and eventual tree death (Percival et al. 2006).

During the first few years of establishment, water is vital to trees for survival. Plant cells are killed or injured by desiccation resulting from moisture lost by transpiration through leaves as the stomata that facilitate photosynthetic gaseous exchange also allow water vapor to escape (Mooney 1982). According to Watson (2001), "maintaining favorable water status is crucial for successful establishment of newly planted trees in the landscape." Because trees are grown in perfect conditions in nurseries, when they are planted outside into harsher urban environments, it is difficult for a tree to adapt. Consequently, the percentage of survival after outplanting has often been low. Improving hardiness against drought before outplanting may ensure greater postplanting survival of newly planted trees. This in turn will reduce labor and replacement cost. Hence, finding exogenous chemicals that improve a plant's stress tolerance may save trees during severe drought conditions (Still and Pill 2004).

Paclobutrazol (PBZ) is a triazole-based plant growth regulator developed by Imperial Chemical Industries, now known as Zeneca and sold under the trade name "Cultar," for use on fruit trees and "Bonsi" for use on ornamentals in the United Kingdom (Fletcher et al. 1986). "Cultar" is formulated in Europe as a suspension concentrate that can be applied as a spray or soil drench treatment. The retardant activity is not accompanied by phytotoxicity or scorch, even when applied at higher rates (Dalziel and Lawrence 1984). The principal mode of action of PBZ is through inhibition of gibberellin biosynthesis (Dalziel and Lawrence 1984). PBZ is readily taken up through the roots, stems, and leaves but is transported almost exclusively in the xylem to its site of action, the subapical meristem, where it has a persistent effect (Anon, 1984). 
Paclobutrazol has been shown to reduce the shoot growth of many tree species (Davis et al. 1985) and is commonly used on trees under utility lines (Watson 1996). According to Watson (2001), the application of PBZ as soil drench treatment at planting time may be able to stimulate root elongation and reduce water stress of trees after transplanting. A further study by Watson (2001) reported that after 10 weeks of drought stress, stem water potential of elms treated with PBZ was the same as the well-watered controls. Indeed, a number of workers conclude that PBZ can be used as a pretreatment to protect plants against drought and increase the percentage of plant survival after transplanting in semiarid climatic conditions (Asare-Boamah et al. 1986; Fletcher et al. 2000; Marshall et al. 2000). In most cases, PBZ-induced drought tolerance has been associated with a decrease in transpiration, plant height, biomass, and leaf area and an increase in stomatal resistance.

Because applications of PBZ increased the stress tolerance of woody plants, it can be suggested that pretreatment application with PBZ would cause an increase in the stress tolerance of other trees species widely planted into urban environments. Such a response may reduce outplanting losses with limited capital investment and only small adjustment to management procedure, the cost of which is negligible compared with the risk of tree death.

The aims of this study are:

- To determine the effectiveness and feasibility of PBZ applied as a root drench and foliar spray to improve the drought tolerance of two urban tree species, evergreen oak (Quercus ilex) and English oak (Q. robur);

- To investigate the concentration conferring maximal resistance to and recovery from drought-induced stress; and

- To evaluate PBZ-induced alterations to plant physiology that could contribute to drought tolerance.

\section{Plant Material}

\section{MATERIALS AND METHODS}

Two plant species were selected for experimental purposes: evergreen oak (Quercus ilex) and English oak (Q. robur). Both species are commonly planted into UK urban environments and provide forms with contrasting drought capabilities. Four-year-old cell-grown stock approximately $90 \mathrm{~cm}$ (36 in) high $\pm 8 \mathrm{~cm}$ (3.2 in) were obtained from a commercial supplier (Alba Trees, Lower Winton, East Lothian, UK). Six months before experiments, trees were potted into $4.5 \mathrm{~L}$ (1.17 gal) plastic pots filled with soil (loamy texture, $24 \%$ clay, $45 \%$ silt, $31 \%$ sand, $3.1 \%$ organic carbon, $\mathrm{pH}$ 6.2) supplemented with the controlled-release nitrogen-based N:P:K (29: 7:9) fertilizer, Bartlett BOOST (The Doggett Corp., Lebanon, $\mathrm{NJ}$ ) at a rate of $1 \mathrm{~g} / \mathrm{kg}$ soil. After potting, trees remained outdoors subject to natural environmental conditions and watered as required. In early April 2005, trees were moved to a polythene tunnel to protect against possible spring frosts. As soon as the initial symptoms of bud burst were observed, i.e., leaf emergence (late April), trees were placed under glasshouse conditions $\left(22^{\circ} \mathrm{C} \pm 2{ }^{\circ} \mathrm{C}\left[71.6^{\circ} \mathrm{F} \pm 35.6^{\circ} \mathrm{F}\right]\right)$ supplemented with $400 \mathrm{~W}$ high-pressure sodium lamps providing a photoperiod of $16 \mathrm{hr}$ light/8hr dark and minimum $250 \mu \mathrm{mol} /$ $\mathrm{m}^{-2} / \mathrm{s}^{-1}$ photosynthetically active radiation (PAR) at the tree crown until PBZ treatments began.

\section{Paclobutrazol Application}

Paclobutrazol treatments were applied when both tree species were in full leaf (2 May 2005). Foliar sprays of PBZ were applied until runoff using a handheld sprayer. As a root drench, PBZ was applied to the substrate surface until fully saturated, i.e., when liquid was seen emerging from the base of the pots. Drenching with distilled water served as the control. Concentrations of PBZ applied were: 1) control (no application of PBZ); 2) $2 \mathrm{~mL}$ (0.06 fl oz) PBZ per liter water applied as spray until runoff; 3) $4 \mathrm{~mL}(0.12 \mathrm{fl} \mathrm{oz}) \mathrm{PBZ}$ per liter water applied as spray until runoff; 4) $5 \mathrm{~mL}(0.15 \mathrm{fl} \mathrm{oz})$ PBZ per $250 \mathrm{~mL}$ ( $7.5 \mathrm{fl} \mathrm{oz})$ water applied as root drench to achieve a concentration of $0.25 \mathrm{~g}(0.01 \mathrm{oz})$ PBZ per $2.5 \mathrm{~cm}$ (1 in) girth, approximately $50 \mathrm{~mL}(1.5 \mathrm{fl} \mathrm{oz})$ per pot; and 5) $10 \mathrm{~mL}(0.3 \mathrm{fl} \mathrm{oz})$ PBZ per $250 \mathrm{~mL}(7.5 \mathrm{fl} \mathrm{oz})$ water applied as root drench to achieve a concentration of $0.50 \mathrm{~g}(0.02 \mathrm{oz})$ PBZ per $2.5 \mathrm{~cm}$ (1 in) girth, approximately $50 \mathrm{~mL}(1.5 \mathrm{fl} \mathrm{oz})$ per pot.

Plants were left for 2 weeks under glasshouse conditions to permit absorption and uptake of PBZ. During this period, plants were watered as required, generally every 3 days. At week 2, after PBZ treatment (16 May 2005), measurements of plant physiology were made.

\section{Drought Treatment and Experimental Design}

Plants were subjected to drought by the cessation of watering for 3 weeks under glasshouse conditions. At week 3 (6 June 2005), a number of physiological measurements were made on leaf tissue as measures of tree vitality. Immediately after measurements, trees were watered as required and placed outdoors subject to natural weather conditions and recovery rates measured over the next 9 weeks at three weekly intervals (27 June, 18 July, 8 August). The experimental design used was a completely randomized block design in which pots were rerandomized on a weekly basis. Ten trees per treatment were used at $0.75 \mathrm{~m}(0.83 \mathrm{ft})$ spacings to prevent competition for light.

\section{Tree Vitality Measurements}

All tree vitality measurements were taken on leaf material present on the plant at the initiation of the experiment (existing leaves). During recovery from drought, new leaf formation was observed at approximately weeks 6 to 7 on both control and PBZ-treated surviving plants. No tree vitality 
measurements were taken on any newly formed leaf tissue, i.e., new leaves not present at the time of PBZ application. At each sampling date, five leaves per tree were used for chlorophyll fluorescence and chlorophyll content measurements randomly selected throughout the crown. Leaves were then tagged to ensure the same leaf was measured throughout the study.

\section{Chlorophyll Fluorescence}

Chlorophyll fluorescence was used as a measure of damage to the leaf photosynthetic system. Leaves were adapted to darkness for $30 \mathrm{~min}$ by attaching light exclusion clips to the leaf surface and chlorophyll fluorescence was measured using a HandyPEA portable fluorescence spectrometer (Hansatech Instruments Ltd., King's Lynn, UK). Measurements were recorded up to $1 \mathrm{sec}$ with a data acquisition rate of $10 \mu \mathrm{s}$ for the first $2 \mathrm{~ms}$ and $1 \mathrm{~ms}$ thereafter. The fluorescence responses were induced by a red (peak at $650 \mathrm{~nm}$ ) light of $1500 \mu \mathrm{mol} /$ $\mathrm{m}^{-2} / \mathrm{s}^{-1}$ PAR intensity provided by an array of six lightemitting diodes. A performance index (PI) based on an equation that combines the relationship of calculated relative number of reaction centers (RC) per energy absorbed (ABS) and then multiplied by two expressions describing the yields of light trapping ( $\phi \mathrm{po})$ and subsequent electron transport $\left(\Psi_{0}\right)$, i.e., $\mathrm{RC} / \mathrm{ABS} \times \phi \mathrm{po} /(1-\phi \mathrm{po}) \times \Psi_{0} /\left(1-\Psi_{0}\right.$; Clark et al. 1998, 2000; Percival and Fraser 2001) was used to quantify any effects on leaf tissue. PI values have been shown to be a highly sensitive measure of leaf photosynthetic activities and provide an indirect measure of plant vitality. PI values were automatically calculated by the HandyPEA.

\section{Leaf Chlorophyll Content}

A Minolta chlorophyll meter SPAD-502 (Spectrum Laboratories, Inc., Plainfield, IL) was used. Chlorophyll was measured at the midpoint of the leaf next to the main leaf vein. Calibration was obtained by measurement of absorbance at 663 and $645 \mathrm{~nm}$ in a spectrophotometer (PU8800 Pye Unicam, Cambridge, UK) after extraction with $80 \%$ v/v aqueous acetone (regression equation $=6.01+0.055 \mathrm{x} ; \mathrm{r}^{2}$ adjusted $=$ 0.90, $P<0.01$ ) (Lichtenthaler and Wellburn 1983).

\section{Photosynthetic $\mathrm{CO}_{2}$ Fixation}

Light-induced $\mathrm{CO}_{2}$ fixation (Pn) was measured in two predarkened (20 min) fully expanded leaves per tree near the top of the canopy (generally approximately the fourth leaf from the apex) using an Infra Red Gas Analyser (LCA-2 ADC; ADC Ltd, Hoddesdon, Herts, UK). The irradiance on the leaves was 700 to $800 \mu \mathrm{mol} / \mathrm{m}^{-2}$ PAR saturating with respect to $\mathrm{Pn}$; the velocity of the airflow was $1 \mathrm{~mL} / \mathrm{s}^{-1} / \mathrm{cm}^{-2}$ leaf area. Calculation of the photosynthetic rates was carried out according to Von Caemmerer and Farquhar (1981). All photosynthetic measurements were taken in the early morning be- tween 8:00 A.M. and 10:00 A.M. on clear or partly cloudy days.

\section{Leaf Necrosis}

Leaf necrosis was assessed visually. Each tree was rated on a 0 to 5 rating scale using a visual indexing technique and ratings on the scale: $0=$ no necrosis observed; $1=$ less than $5 \%$ of leaves affected and no aesthetic impact; $2=5 \%$ to $20 \%$ of leaves affected with some yellowing but little or no defoliation; $3=21 \%$ to $50 \%$ of leaves affected, significant defoliation and/or leaf yellowing; $4=51 \%$ to $80 \%$ of leaves affected, severe foliar discoloration; and $5=81 \%$ to $100 \%$ of foliage affected with $90 \%$ to $100 \%$ defoliation.

\section{Leaf Electrolyte Leakage}

Quantitative drought damage to leaf tissue was assessed by measuring electrolyte leakage of entire leaves (two leaves per tree) at each sampling date. Excised leaves were placed in 50 $\mathrm{mL}(1.5 \mathrm{fl} \mathrm{oz})$ universal bottles containing $30 \mathrm{~mL}(0.9 \mathrm{fl} \mathrm{oz})$ distilled water and gently shaken by hand. Samples were stored at $22^{\circ} \mathrm{C}\left(71.6^{\circ} \mathrm{F}\right)$ for $24 \mathrm{hr}$ in darkness before conductivity measurements using a Jenway conductivity probe and M4070 m (BDH, Leicestershire, Loughborough, UK). Total solute leakage was obtained by autoclaving for $1 \mathrm{hr}$ at $121^{\circ} \mathrm{C}$ $\left(249.8^{\circ} \mathrm{F}\right)$ and $0.103 \mathrm{MPa}$. Results are presented as percent solute leakage after $24 \mathrm{hr}$ (McKay 1992)

\section{Carotenoids}

Carotenoids (lutein, $\beta$-carotene, neoxanthin, $\alpha$-carotene, zeaxanthin, antheraxanthin, violaxanthin) were analyzed using a high-performance liquid chromatography (HPLC) system (Schindler and Lichtenthaler 1994). Leaf samples were excised from trees and immediately placed in liquid nitrogen. Fifty leaf samples per treatment, i.e., five leaves per tree, were taken. Pigment analysis was performed the next day. Pigments were extracted from leaves with $100 \%$ aqueous acetone (quartz sand mortar) and separated and quantitatively determined by reverse-phase HPLC applying a Nucleosil $\mathrm{C}_{18}$ column (particle size $4 \mu \mathrm{m}$ ). The solvent systems for the combined isocratic and gradient separation and quantification were acetonitrile-methanol-0.2 $\mathrm{M}$ tris/HCL buffer and methanol-hexane (Lichtenthaler et al. 1992).

\section{Superoxide Dismutase Activity}

Superoxide dismutase (SOD) activity was based on the method described by Kraus and Fletcher (1994). In summary, extracts were prepared at $4^{\circ} \mathrm{C}\left(39.2^{\circ} \mathrm{F}\right)$ by homogenizing 0.2 $\mathrm{g}(0.07 \mathrm{oz})$ of leaf tissue (generally three leaves per plant) in $4 \mathrm{~mL}(0.12 \mathrm{fl} \mathrm{oz})$ of $0.1 \mathrm{M} \mathrm{Na}_{2} \mathrm{HPO}_{4} / \mathrm{NaH}_{2} \mathrm{PO}_{4}$ buffer $(\mathrm{pH} 7)$ with a mortar and pestle and centrifuged at $16,000 \times g$ for 10 min. The supernatant was filtered through Watman paper (No. 1) (Sigma-Aldrich, Poole, UK) and $1 \mathrm{~mL}(0.03 \mathrm{fl} \mathrm{oz})$ was applied to a Pharmacia PD-10 chromatography column (Waters HPLC Solutions, Centennial Park, Elstree, Hertfordshire, UK) containing Sephadex G-250 (Waters HPLC Solu- 
tions) equilibrated with $50 \mathrm{mM} \mathrm{Na} \mathrm{CO}_{3}$ buffer ( $\mathrm{pH} 10.2$ ) to remove low-molecular-weight components and exchange the buffer. The assay was performed using $0.1 \mathrm{mM}$ diethylenetriaminepentaacetic acid in the reaction mixture and the subsequent increase in absorbance at $550 \mathrm{~nm}$ followed on a spectrophotometer (PU8800 Pye Unicam) equipped with a kinetics module for $6 \mathrm{~min}$ at $24^{\circ} \mathrm{C}\left(75.2^{\circ} \mathrm{F}\right)$.

\section{Catalase Activity}

A total of $0.3 \mathrm{~g}(0.11 \mathrm{oz})$ of foliar tissue (generally five leaves per plant) were homogenized in $5 \mathrm{~mL}(0.15 \mathrm{fl} \mathrm{oz})$ of $0.2 \mathrm{M}$ Tris- $\mathrm{Cl}^{-}$(buffer $\mathrm{pH}$ 7.8) containing $0.13 \mathrm{mM}$ EDTA and 80 $\mu \mathrm{M}$ soluble polyvinylpyrrolidone with a Polytron homogenizer (Glen Mills, Clifton, NJ) for $30 \mathrm{sec}$ on ice and centrifuged at $3000 \times g$ for $10 \mathrm{~min}$. Catalase activity was determined by following the consumption of hydrogen peroxide (extinction coefficient $39.4 \mathrm{~mm}^{-1} / \mathrm{cm}^{-1}$ ) at $240 \mathrm{~nm}$ for $2 \mathrm{~min}$. The reaction mixture contained $2 \mathrm{~mL}$ of $100 \mathrm{mM} \mathrm{Na}_{2} \mathrm{HPO}_{4} /$ $\mathrm{NaH}_{2} \mathrm{PO}_{4}$ buffer ( $\mathrm{pH} 6.5$ ) and $50 \mu \mathrm{L}$ of plant extract and the reaction was initiated by adding $10 \mu \mathrm{L}$ of $30 \%(\mathrm{w} / \mathrm{v})$ hydrogen peroxide.

\section{Proline}

Leaf samples ( $1 \mathrm{~g}[0.035 \mathrm{oz}])$ were extracted with $3 \%$ sulphosalicylic acid. Extracts $(2 \mathrm{~mL}[0.06 \mathrm{fl} \mathrm{oz}])$ were held for $1 \mathrm{hr}$ in boiling water by adding $2 \mathrm{~mL}(0.06 \mathrm{fl} \mathrm{oz})$ ninhydrin and $2 \mathrm{~mL}(0.06 \mathrm{fl} \mathrm{oz})$ glacial acetic acid after which cold toluene $(4 \mathrm{~mL}[0.12 \mathrm{fl} \mathrm{oz}])$ was added. Proline content was measured by a spectrophotometer (Shimadzu UV 1601; Shimadzu UK, Milton Keynes, Buckinghamshire, England) at $520 \mathrm{~nm}$ and calculated as $\mu \mathrm{g} / \mathrm{g}$ dry leaf weight against standard proline.

\section{Plant Height and Leaf Mean Leaf Area}

At the cessation of the experiment, trees were destructively harvested and height recorded by measuring the distance from the tip of the leading apical shoot to the soil surface. Mean leaf size was calculated by quantifying total leaf area per tree using a Delta-T leaf area meter (Delta-T Devices, Cambridge, UK) and dividing by the total number of leaves per tree.

\section{Statistical Analysis}

Data for each species was analyzed independently by oneway analysis of variance using the Genstat V program (Committee of the Statistics Department, Rothamsted Experimental Station, Harpenden, Hertfordshire, UK) for Windows. Before the analysis, data were examined for normality and homogeneity of variance (Levene 1960) and data were transformed $[\log (y+0.5)]$ when necessary. When significant differences occurred, the means were separated by least significant difference test $(P<0.05)$. Survival recorded as percentage and visual leaf necrosis were analyzed after appropriate statistical transformation $\left(\arcsin \left[\mathrm{x}^{0.5}\right]\right)$. Because measurements over time were obtained from the same plant, the relationship between chlorophyll fluorescence and SPAD readings over time after PBZ treatments was quantified using repeated measures analysis (quadratic regression).

\section{RESULTS}

\section{Basal Alterations to Plant Physiology 2 Weeks After Paclobutrazol Application}

Irrespective of concentration applied and mode of application (foliar spray or root drench), PBZ induced a number of significant $(P<0.05)$ changes in whole plant physiology of both English and evergreen oak compared with nonPBZ-treated controls (Tables 1 and 2). Leaf membrane integrity as assessed by leakiness of leaf tissue was reduced by $14 \%$ to $34 \%$, whereas PI and Pn was increased by 3 to 17 and $3 \%$ to $18 \%$, respectively, in both test species (Tables 1 and 2). In all cases, PBZ-treated plants had a higher leaf content of total carotenoids and chlorophylls with levels increased by 14 to 25 and $12 \%$ to $29 \%$, respectively, compared with nonPBZ-treated controls. Similar percentage increases were recorded in the leaf content of carotenoids (lutein: $\beta$ carotene:neoxanthin: $\alpha$-carotene) and xanthophylls (zeaxanthin:antheraxanthin:violaxanthin), although no effects were found on their ratios (Tables 1 and 2). No PBZ-induced effects were found on the ratio of chlorophyll $\mathrm{a} / \mathrm{b}$ in comparison with control plants. Irrespective of species, PBZ-treated plants had $4 \%$ to $20 \%, 8 \%$ to $31 \%$, and $9 \%$ to $37 \%$ more proline, superoxide dismutase, and catalase, respectively, than controls. No symptoms of phytotoxicity were observed at week 2 after PBZ application, i.e., no leaf necrosis observed on foliage of evergreen oak and leaf necrosis values ranging from 0 to 0.4 in $(0$ to $0.16 \mathrm{~cm}$ ) English oak (Tables 1 and 2).

\section{Chlorophyll Fluorescence, Light-induced Photosynthetic $\mathrm{CO}_{2}$ Fixation, Membrane Integrity, Leaf Chlorophyll Content, and Necrosis at Week 3 Postdrought Treatment}

Irrespective of concentration or mode of application (foliar spray, root drench), in all cases, PBZ protected both English and evergreen oak from injury resulting from drought as manifest by reduced mortality in PBZ-treated trees compared with non-PBZ-treated controls (Tables 3 and 4). Such a response was particularly pronounced in English oak in which all PBZ-treated trees survived a 3-week drought period compared with controls in which a significantly lower $20 \%$ survival rate was recorded (Table 3). In the case of English oak, PI values as a measure of leaf photosynthetic efficiency, Pn, and leaf chlorophyll content were all significantly $(P<0.05)$ higher than non-PBZ-treated controls (Table 3 ). A similar response was recorded in evergreen oak in which in all cases, PI, Pn, and leaf chlorophyll content were always higher than non-PBZ-treated controls, if not significantly so in every in stance. Such a response indicates reduced damage to the leaf 


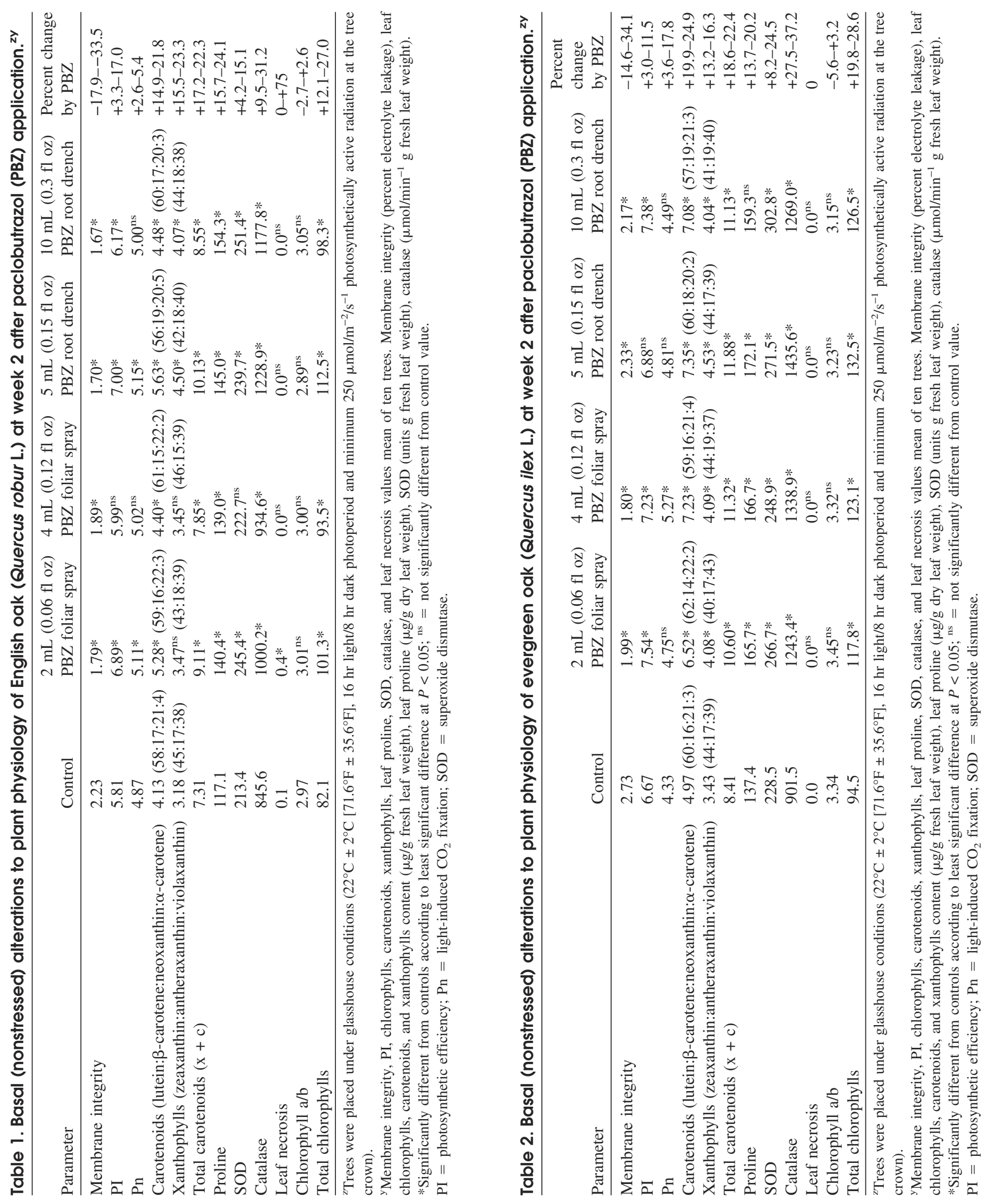


Table 3. The effects of 21 days of drought on chlorophyll fluorescence (PI), photosynthetic $\mathrm{CO}_{2}$ fixation (Pn), leaf chlorophyll content, and necrosis of containerized English oak (Quercus robur L.). ${ }^{2 y}$

\begin{tabular}{|c|c|c|c|c|c|c|}
\hline & PI & Pn & $\begin{array}{l}\text { Chlorophyll } \\
\text { content }\end{array}$ & $\begin{array}{l}\text { Leaf } \\
\text { necrosis }\end{array}$ & $\begin{array}{l}\text { Membrane } \\
\text { integrity }\end{array}$ & $\begin{array}{l}\text { Survival } \\
(\%)\end{array}$ \\
\hline Control & 0.18 & 1.87 & 30.9 & 4.1 & 27.2 & 20 \\
\hline $4 \mathrm{~mL}(0.12 \mathrm{fl} \mathrm{oz}) \mathrm{PBZ}$ foliar spray & $2.02 *$ & $3.42 *$ & $41.1^{*}$ & $2.1^{*}$ & $8.9^{*}$ & $100^{*}$ \\
\hline $5 \mathrm{~mL}(0.15 \mathrm{fl} \mathrm{oz}) \mathrm{PBZ}$ root drench & $1.68 *$ & $3.52 *$ & $48.3^{*}$ & $1.9 *$ & $13.2^{*}$ & $100 *$ \\
\hline $10 \mathrm{~mL}(0.3 \mathrm{fl} \mathrm{oz}) \mathrm{PBZ}$ root drench & $2.41 *$ & $3.58 *$ & $42.2 *$ & $2.0^{*}$ & $9.5^{*}$ & $100^{*}$ \\
\hline
\end{tabular}

${ }^{\mathrm{z}}$ Measurements were made immediately at the cessation of the drought treatment when trees were placed under glasshouse conditions $\left(22^{\circ} \mathrm{C} \pm 2{ }^{\circ} \mathrm{C}\left[71.6^{\circ} \mathrm{F} \pm\right.\right.$ $\left.35.6^{\circ} \mathrm{F}\right], 16 \mathrm{hr}$ light $/ 8 \mathrm{hr}$ dark photoperiod and minimum $250 \mu \mathrm{mol} / \mathrm{m}^{-2} / \mathrm{s}^{-1}$ photosynthetically active radiation at the tree crown.

${ }^{\mathrm{y}}$ PBZ-treated plants: PI and leaf chlorophyll content, values mean of ten trees, five leaves per tree. Pn and electrolyte leakage values mean of ten trees, two leaves per tree. Leaf necrosis values mean of ten trees. Controls: PI and leaf chlorophyll content, values mean of two trees, five leaves per tree. Pn and electrolyte leakage values mean of two trees, two leaves per tree. Leaf necrosis values mean of two trees.

*Significantly different from controls according to least significant difference at $P<0.05 ;^{\text {ns }}=$ not significantly different from control value. PBZ = paclobutrazol.

photosynthetic system and greater structural integrity of the chlorophyll molecule at the cessation of the drought period. Leaf electrolyte leakage as a measure of drought-induced damage to cellular membrane integrity was reduced by $49 \%$ to $67 \%$ in the case of PBZ-treated English oak and by $28 \%$ to $48 \%$ in the case of PBZ-treated evergreen oak compared with control values (Tables 3 and 4). Similarly, visual leaf necrosis was reduced by $51 \%$ to $56 \%$ in the case of PBZ-treated English oak and by $21 \%$ to $37 \%$ in the case of PBZ-treated evergreen oak compared with control values (Tables 3 and 4). In most cases, these reductions were significant $(P<0.05)$ from controls (Tables 3 and 4).

\section{Effects of Paclobutrazol on Drought Recovery Rates}

The pattern of recovery over the next 9 weeks after 3 weeks of drought on PI, leaf necrosis, chlorophyll content, and cel- lular electrolyte leakage is shown for English and evergreen oak (Tables 5 and 6). In addition, the pattern of recovery is shown diagrammatically for both species with respect to leaf chlorophyll content (Figures 1 and 2). Irrespective of treatment (with or without PBZ), all four parameters began to recover in surviving trees after the start of watering. Consequently, the pattern of recovery was quantified by quadratic regression analysis to compare the rate of recovery over the next 9 weeks (Tables 5 and 6). Irrespective of species, all PBZ-treated trees were the most capable of recovery as reflected by higher regression values with respect to PI and leaf chlorophyll recovery and lower regression values with respect to leaf necrosis and cellular electrolyte leakage (Tables 5 and 6). Such responses in PBZ-treated trees are associated with enhanced recovery of leaf photosynthetic integrity, improved photosynthetic efficiency, reduced degradation of the chlorophyll molecule structure, and enhanced membrane in-

Table 4. The effects of 21 days of drought on chlorophyll fluorescence (PI), photosynthetic $\mathrm{CO}_{2}$ fixation (Pn), leaf chlorophyll content, and necrosis of containerized evergreen oak (Quercus ilex L.). ${ }^{z y}$

\begin{tabular}{|c|c|c|c|c|c|c|}
\hline & PI & Pn & $\begin{array}{l}\text { Chlorophyll } \\
\text { content }\end{array}$ & $\begin{array}{l}\text { Leaf } \\
\text { necrosis }\end{array}$ & $\begin{array}{l}\text { Membrane } \\
\text { integrity }\end{array}$ & $\begin{array}{l}\text { Survival } \\
(\%)\end{array}$ \\
\hline Control & 1.70 & 1.59 & 50.6 & 3.8 & 25.4 & 40 \\
\hline $4 \mathrm{~mL}(0.12 \mathrm{fl} \mathrm{oz}) \mathrm{PBZ}$ foliar spray & $2.57^{\mathrm{ns}}$ & $1.98^{\mathrm{ns}}$ & $61.0^{\mathrm{ns}}$ & $2.8^{\mathrm{ns}}$ & $17.4^{\mathrm{ns}}$ & $60^{\mathrm{ns}}$ \\
\hline $5 \mathrm{~mL}(0.15 \mathrm{fl} \mathrm{oz}) \mathrm{PBZ}$ root drench & $2.42^{\mathrm{ns}}$ & $2.07^{\mathrm{ns}}$ & $68.7^{\mathrm{ns}}$ & $3.0^{\mathrm{ns}}$ & $16.0^{\mathrm{ns}}$ & $80 *$ \\
\hline $10 \mathrm{~mL}(0.3 \mathrm{fl} \mathrm{oz}) \mathrm{PBZ}$ root drench & $3.34 *$ & $1.78^{\mathrm{ns}}$ & $84.3^{*}$ & $2.4^{\mathrm{ns}}$ & $12.3^{*}$ & $60^{\mathrm{ns}}$ \\
\hline
\end{tabular}

${ }^{\mathrm{z}}$ Measurements were made immediately at the cessation of the drought treatment when trees were placed under glasshouse conditions $\left(22^{\circ} \mathrm{C} \pm 22^{\circ} \mathrm{C}\left[71.6^{\circ} \mathrm{F} \pm\right.\right.$ $35.6^{\circ} \mathrm{F}$ ], $16 \mathrm{hr}$ light $/ 8 \mathrm{hr}$ dark photoperiod and minimum $250 \mu \mathrm{mol} / \mathrm{m}^{-2} / \mathrm{s}^{-1}$ photosynthetically active radiation at the tree crown).

${ }^{\mathrm{y}}$ Two milliliters PBZ foliar spray and $5 \mathrm{~mL}(0.15 \mathrm{fl} \mathrm{oz}) \mathrm{PBZ}$ root drench-treated plants: PI and leaf chlorophyll content, values mean of eight trees, five leaves per tree. Pn and electrolyte leakage values mean of eight trees, two leaves per tree. Leaf necrosis values mean of ten trees. Four milliliters PBZ foliar spray and $10 \mathrm{~mL}(0.3 \mathrm{fl} \mathrm{oz})$ PBZ root drench-treated plants: PI and leaf chlorophyll content, values mean of six trees, five leaves per tree. Pn and electrolyte leakage values mean of six trees, two leaves per tree. Leaf necrosis values mean of ten trees. Controls: PI and leaf chlorophyll content, values mean of four trees, five leaves per tree. Pn and electrolyte leakage values mean of four trees, two leaves per tree.

*Significantly different from controls according to least significant difference at $P<0.05$; ${ }^{\text {ns }}=$ not significantly different from control value. $\mathrm{PBZ}=$ paclobutrazol. 
Table 5. Paclobutrazol enhanced recovery of leaf PI, necrosis, and chlorophyll content of containerized English oak (Quercus robur L.) placed outdoors with time (9 weeks) based on quadratic regression analysis after the cessation of 3 weeks of drought.

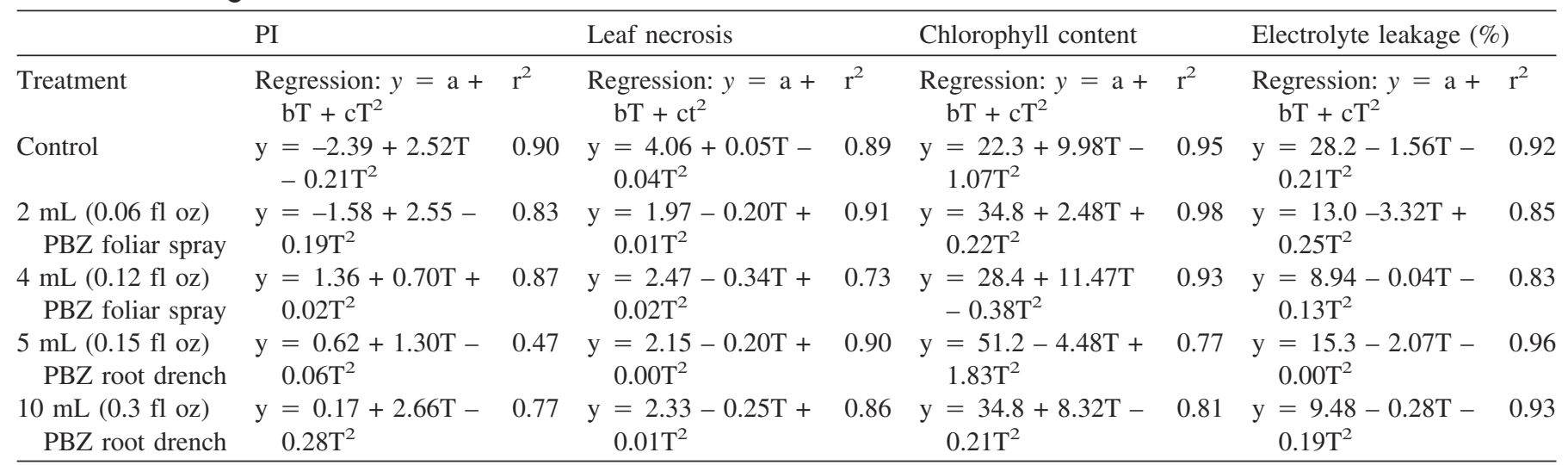

${ }^{\mathrm{z}}$ PBZ-treated plants: PI and leaf chlorophyll content, values mean of ten trees, five leaves per tree. Electrolyte leakage values mean of ten trees, two leaves per tree. Leaf necrosis values mean of ten trees. Controls: PI and leaf chlorophyll content, values mean of two trees, five leaves per tree. Pn and electrolyte leakage values mean of two trees, two leaves per tree. Leaf necrosis values mean of two trees.

$\mathrm{y}=$ leaf PI, necrosis, chlorophyll content, and electrolyte leakage value; a = leaf PI, necrosis, chlorophyll content, and electrolyte leakage of control value (calculated intercept); b = rate of PI, necrosis, chlorophyll content and electrolyte leakage with time $(\mathrm{T}) ; \mathrm{c}=$ rate of change of leaf PI, necrosis, chlorophyll content, and electrolyte leakage.

PBZ = paclobutrazol; PI = chlorophyll fluorescence.

tegrity compared with non-PBZ-treated trees (controls). Overall, recovery (PI, leaf chlorophyll content, necrosis, electrolyte leakage) rates of drought-damaged trees treated with PBZ ranged from $20 \%$ to $50 \%$ higher than non-PBZ-treated trees (Tables 5 and 6). In all cases, control trees (non-PBZtreated) had the least capacity for recovery. In both English and evergreen oak, no major differences in recovery rates were recorded between PBZ-treated trees irrespective of

Table 6. Paclobutrazol enhanced recovery of leaf PI, necrosis, and chlorophyll content of containerized evergreen oak (Quercus ilex L.) placed outdoors with time (9 weeks) based on quadratic regression analysis after the cessation of 3 weeks of drought. ${ }^{2}$

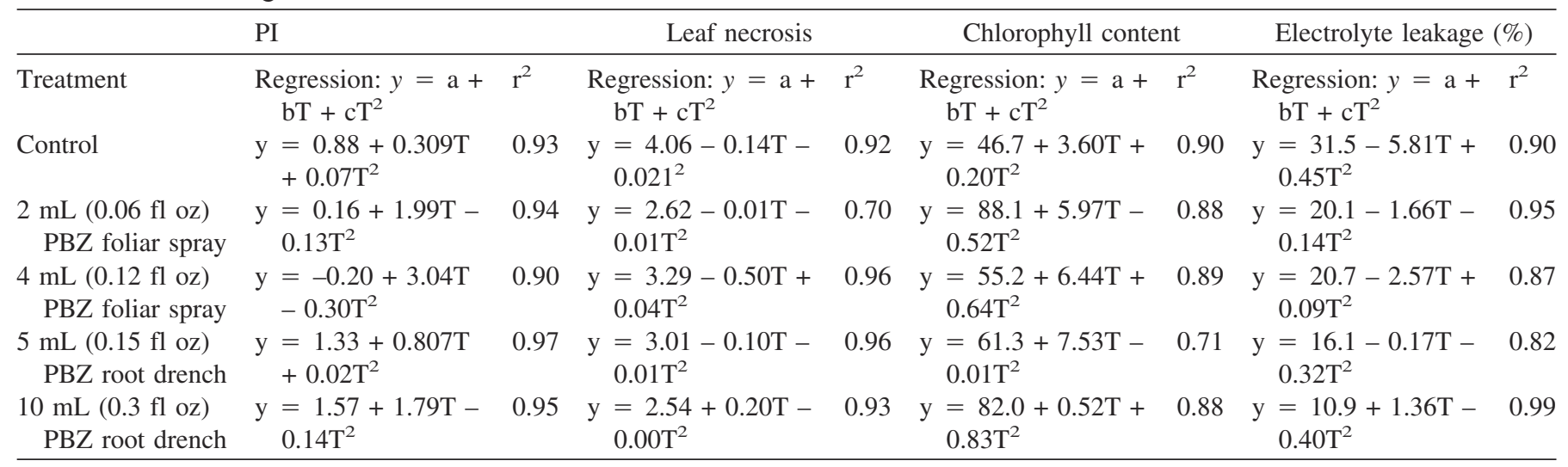

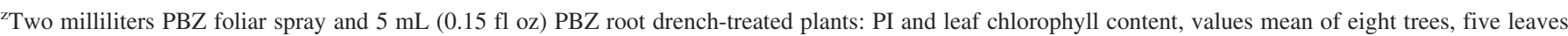
per tree. Pn and electrolyte leakage values mean of eight trees, two leaves per tree. Leaf necrosis values mean of eight trees. Four milliliters PBZ foliar spray and $10 \mathrm{~mL}(0.3 \mathrm{fl} \mathrm{oz}) \mathrm{PBZ}$ root drench-treated plants: PI and leaf chlorophyll content, values mean of six trees, five leaves per tree. Pn and electrolyte leakage values mean of six trees, two leaves per tree. Leaf necrosis values mean of six trees. Controls: PI and leaf chlorophyll content, values mean of four trees, five leaves per tree. Pn and electrolyte leakage values mean of four trees, two leaves per tree. Leaf necrosis values mean of four trees.

$\mathrm{y}=$ leaf PI, necrosis, chlorophyll content, and electrolyte leakage value; a = leaf PI, necrosis, chlorophyll content, and electrolyte leakage of control value (calculated intercept); b = rate of PI, necrosis, chlorophyll content, and electrolyte leakage with time (T); c = rate of change of leaf PI, necrosis, chlorophyll content, and electrolyte leakage.

$\mathrm{PBZ}=$ paclobutrazol; $\mathrm{PI}=$ chlorophyll fluorescence; $\mathrm{Pn}=$ photosynthetic $\mathrm{CO}_{2}$ fixation 
Table 7. Influence of PBZ on height and mean leaf size of containerized English (Quercus robur L.) and evergreen oak (Quercus ilex L.) placed outdoors over a 9-week period after the cessation of a 3-week drought period.

\begin{tabular}{|c|c|c|c|c|}
\hline \multirow[b]{2}{*}{ Treatment } & \multicolumn{2}{|c|}{ Evergreen Oak } & \multicolumn{2}{|c|}{ English Oak } \\
\hline & $\begin{array}{l}\text { Height } \\
(\mathrm{m})\end{array}$ & $\begin{array}{l}\text { Mean leaf } \\
\text { size }\left(\mathrm{cm}^{2}\right)\end{array}$ & $\begin{array}{l}\text { Height } \\
(\mathrm{m})\end{array}$ & $\begin{array}{l}\text { Mean leaf } \\
\text { size }\left(\mathrm{cm}^{2}\right)\end{array}$ \\
\hline Control & 1.05 & 8.9 & 1.15 & 49.3 \\
\hline $2 \mathrm{~mL}(0.06 \mathrm{fl} \mathrm{oz}) \mathrm{PBZ}$ & $0.96^{\mathrm{ns}}$ & $8.4^{\mathrm{ns}}$ & $0.99^{\mathrm{ns}}$ & $43.1^{\mathrm{ns}}$ \\
\hline $\begin{array}{l}4 \mathrm{~mL}(0.12 \mathrm{fl} \mathrm{oz}) \mathrm{PBZ} \\
\text { foliar spray }\end{array}$ & $0.83^{\mathrm{ns}}$ & $6.0^{*}$ & $0.86^{*}$ & $32.2 *$ \\
\hline $\begin{array}{l}5 \mathrm{~mL}(0.15 \mathrm{fl} \mathrm{oz}) \mathrm{PBZ} \\
\text { root drench }\end{array}$ & $0.79 *$ & $4.5^{*}$ & $0.80^{*}$ & $28.5^{*}$ \\
\hline $\begin{array}{l}10 \mathrm{~mL}(0.3 \mathrm{fl} \mathrm{oz}) \mathrm{PBZ} \\
\text { root drench }\end{array}$ & $0.68 *$ & $4.3^{*}$ & $0.76^{*}$ & $26.7 *$ \\
\hline LSD & 0.245 & 2.759 & 0.276 & 15.26 \\
\hline
\end{tabular}

${ }^{\mathrm{z}}$ English oak PBZ-treated plants: all values mean of ten trees. English oak control: all values mean of two trees.

Evergreen oak $2 \mathrm{~mL}(0.06 \mathrm{fl} \mathrm{oz}) \mathrm{PBZ}$ foliar spray and $5 \mathrm{~mL}(0.15 \mathrm{fl} \mathrm{oz}) \mathrm{PBZ}$ root drench-treated plants mean of eight trees. Four milliliters PBZ foliar spray and $10 \mathrm{~mL}(0.3 \mathrm{fl} \mathrm{oz}) \mathrm{PBZ}$ root drench-treated plants mean of six trees. Controls mean of four trees.

*Significantly different from controls according to least significant difference (LSD) at $P<0.05 ;^{\text {ns }}=$ not significantly different from control value. $\mathrm{PBZ}=$ paclobutrazol.

mode of application (foliar spray or root drench) and concentration applied. None of the treatments used in this investigation altered the ratio of chlorophyll $a: b$ in English (2.953.19) or evergreen oak (3.14-3.38; data not shown).

\section{Plant Height and Mean Leaf Size}

During the drought recovery phase, new leaf formation was observed at approximately weeks 4 to 6 on both control and PBZ-treated surviving trees. Distinct symptoms of overregulation, i.e., stunted leaf formation were visibly noticeable in plants treated with $4 \mathrm{~mL}(0.12 \mathrm{fl} \mathrm{oz}) \mathrm{PBZ}$ per liter as a foliar spray and PBZ as a root drench at both 5 and $10 \mathrm{~mL}(0.15$ and $0.3 \mathrm{fl} \mathrm{oz}$ ) per $250 \mathrm{~mL}$ (7.5 fl oz) water (Table 7). Indeed, a significant $(P<0.05)$ reduction in leaf size and height was recorded in both evergreen and English oak at the cessation of the experiment after these treatments. Trees sprayed with 2 $\mathrm{mL}(0.06 \mathrm{fl} \mathrm{oz})$ PBZ per liter had a smaller mean leaf size and height than controls but not significantly so.

\section{DISCUSSION}

Results of this study showed that pretreatment of English and evergreen oak with PBZ as a foliar spray or root drench induced a suite of physiological adaptations that would allow both species to tolerate drought after transplanting. Such a

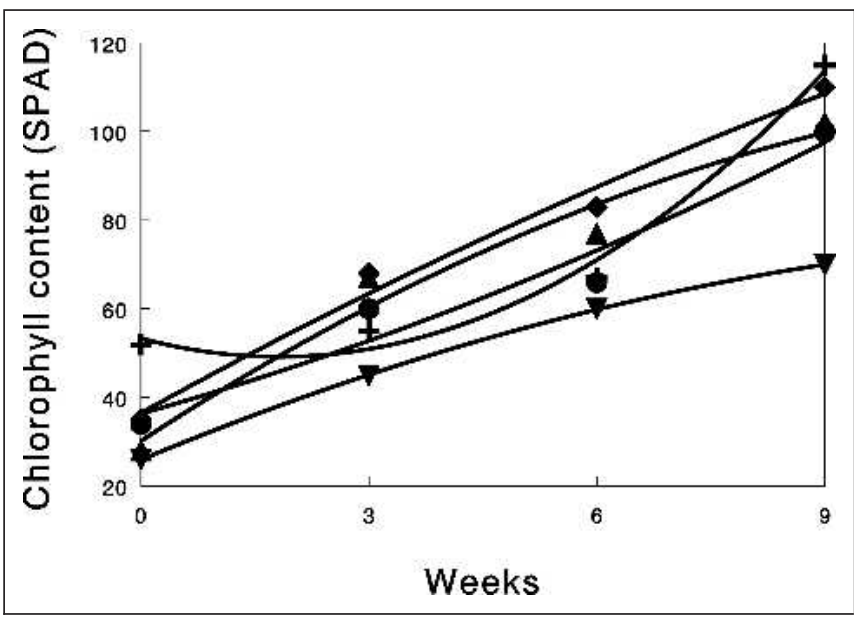

Figure 1. Time course recovery of leaf chlorophyll content (SPAD values) of evergreen oak (Quercus robur L.) placed outdoors after a 21-day drought period. Paclobutrazol (PBZ)-treated plants mean of ten trees, five leaves per tree. Controls, values mean of mean of two trees, five leaves per tree. $\boldsymbol{\nabla}=$ Control; $\boldsymbol{\Delta}=2 \mathrm{~mL}$ PBZ foliar spray; $=4 \mathrm{~mL}$ PBZ foliar spray; + = $5 \mathrm{~mL}$ PBZ root drench; $\checkmark=10 \mathrm{~mL}$ PBZ root drench.

response is particularly noticeable in English oak in which drought-related mortality rates were reduced by $80 \%$. More specifically, PBZ strengthened leaf membrane integrity, increased leaf PI, Pn, total leaf content of carotenoids (lutein: $\beta$ carotene:neoxanthin: $\alpha$-carotene) and xanthophylls (zeaxanthin:antheraxanthin:violaxanthin), chlorophylls, proline, SOD, and catalase. No marked differences were observed after application of PBZ as a root drench or foliar spray, although previous research suggests PBZ application has a greater efficiency as a substrate drench than as spray treatment (Davis et al. 1988; Bañón et al. 2002).

One of the initial plant responses to drought is stomatal closure to conserve transpirational water loss. Such a response can be highly detrimental to the leaf photosynthetic system as a result of the prevention of light energy conversion into electrochemical energy caused by low $\mathrm{CO}_{2}$ concentrations within the leaf tissue, in turn resulting in the production of high-energy reactive oxygen species (ROS) such as superoxide and singlet oxygen (Lawlor 2001). Singlet oxygen and other ROS are highly toxic compounds that cause acute membrane damage. Unchecked ROS can be converted into hydrogen peroxide (bleach), which diffuses over much greater distances and causes further oxidative damage such as chlorophyll bleaching and cellular membrane destruction. To minimize the effects of oxidative stress induced by drought stress, plants have evolved a complex antioxidant system, which is composed of low-molecular mass antioxidants such 


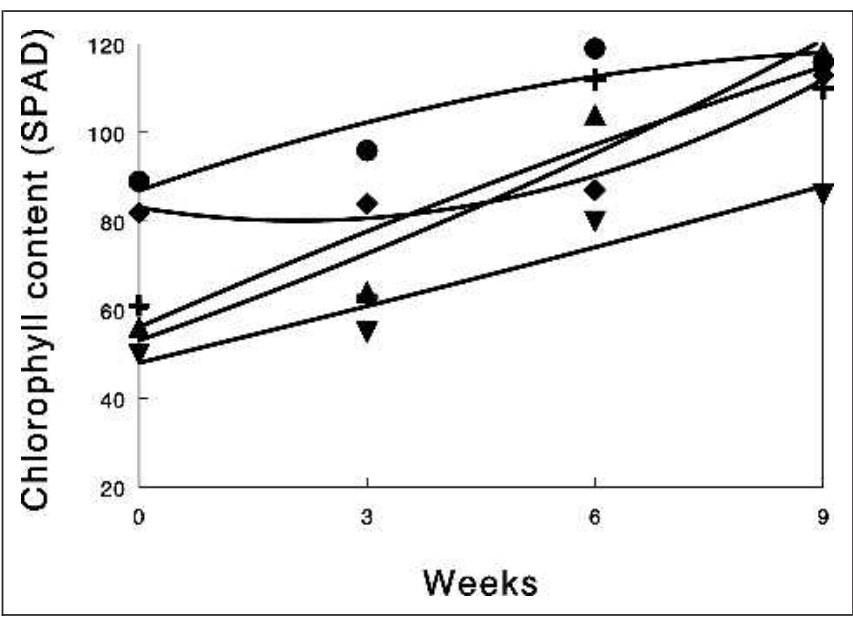

Figure 2. Time course recovery of leaf chlorophyll content (SPAD values) of evergreen oak (Quercus ilex L.) placed outdoors after a 21-day drought period. Two milliliters paclobutrazol (PBZ) foliar spray and $5 \mathrm{~mL}$ PBZ root drenchtreated plant values mean of eight trees, five leaves per tree. Four milliliters PBZ foliar spray and $10 \mathrm{~mL}$ PBZ root drench-treated plant values mean of six trees, five leaves per tree. Controls, values mean of mean of four trees, five leaves per tree. $\boldsymbol{\nabla}=$ Control; $\Delta=2 \mathrm{~mL}$ PBZ foliar spray; $-=4 \mathrm{~mL}$ PBZ foliar spray; + = $5 \mathrm{~mL} \mathrm{PBZ}$ root drench; $\$=10$ $\mathrm{mL}$ PBZ root drench.

as carotenoids as well as ROS-scavenging enzymes such as SOD and calatase (CAT; Apel and Hirt 2004). Relatively higher activities of ROS-scavenging enzymes have been reported in stress-tolerant genotypes when compared with susceptible ones, suggesting that these antioxidant enzymes plays an important role in plant tolerance against environmental stresses such as salinity and drought (Apel and Hirt 2004). In the current study, a significant increase in leaf SOD and CAT activity was observed in both PBZ-treated English and evergreen oak. The function of SOD is to scavenge superoxide in the chloroplast and catalyze the first step in the detoxification of active oxygen to $\mathrm{H}_{2} \mathrm{O}_{2} \cdot \mathrm{H}_{2} \mathrm{O}_{2}$ is then scavenged by catalase resulting in the dismutation of $\mathrm{H}_{2} \mathrm{O}_{2}$ to water and oxygen. Likewise, carotenoids (carotenes and xanthoylls) function as protective photooxidative pigments responsible for the quenching of chlorophyll excited states, singlet oxygen, and interception of deleterious free oxygen and organic radicals caused by drought-induced photoinhibition (Lawlor 2001). Enhanced leaf concentrations of carotenes and xanthoylls recorded in PBZ-treated plants before the start of the drought treatment imposed in this investigation would be important contributors to reducing droughtinduced photoinhibitory damage to plant cellular membranes and the photosynthetic system (Kraus and Fletcher 1994).
In this experiment, an increase in the amino acid proline in plants treated by PBZ was observed. The function of proline is to reduce the osmotic potential so that the water potential gradient favors water uptake and therefore the plant can maintain turgor, for example, under drought or salinity conditions. The advantage of osmotic adjustment to the plant is that water potential across cells and tissues is maintained against a fall in water potential during drought, in turn preventing or reducing whole plant turgor. In addition, it is suggested that proline may also protect protein configurations during dehydration (Fernandez et al. 2006). Consequently, an increase in leaf proline concentration would permit a more favorable water uptake under water stress conditions improving the adaptation of plants to drought conditions. The association between increased proline concentration and tolerance to drought has been shown elsewhere (De Ronde et al. 2000; Ain-Lhout et al. 2001; Jiang and Huang 2001; Ehmedov et al. 2002; Yamada et al. 2005). Likewise, exogenously applied proline has been shown to significantly increase the stress tolerance of a broad range of plants (Van Swaaij et al. 1985; Songstad et al. 1990; Santarius 1992). With the exception of these experiments, few studies have observed the direct effect of PBZ on proline accumulation within plant tissue, although a number of examples exist showing a subsequent increase in leaf protein (to include proline) concentrations post PBZ application (Sankhla et al. 1992; Kraus and Fletcher 1994).

The chlorophyll fluorescence PI value is a measure of leaf photosynthetic efficiency and subsequently provides an indirect measure of tree vitality (Clark et al. 1998, 2000). A decline in this value is a sensitive indicator of photoinhibitory damage caused by a wide range of environmental stresses such as salinity, drought, and ozone exposure. After exposure to 3 weeks of drought, the PI value in the PBZ-treated trees was substantially higher than non-PBZ-treated controls. Thus, the plants treated with PBZ were found to be from $60 \%$ to greater than $100 \%$ more efficient photosynthetically. The maintenance of relatively high fluorescence values in PBZtreated plants under stress has been observed in previous studies (Pinhero and Fletcher 1994). Increased photosynthetic efficiency permits increased metabolic activity within the plant such as synthesis of sugars, amino acids, proteins, nucleic acids, and lipids, essential for the growth and repair of damaged tissue. If the photosynthetic system is impaired, then the carbohydrates required for repair and growth cannot be produced. Higher PI values in PBZ-treated plants indicate less damage to the leaf photosynthetic system in turn manifest by a greater ability to repair damaged tissue, grow, and survive after the cessation of drought (Percival et al. 2006).

Leakiness of leaf tissue, determined from electrolyte leakage, indicated that cellular membrane integrity was damaged more rapidly in non-PBZ-treated controls compared with PBZ-treated plants at the cessation of 3 weeks of drought. 
Stem electrolyte leakage indicates tissue damage resulting in the loss of cell membrane semipermeability (Cameron and Dixon 1997). The principle of electrolyte leakage is that the movement of cell contents to and from cells is controlled mainly by the structural proteins present at points along the lipid bilayer of the cell membrane. When healthy plant tissue is immersed in ion-free water, there is a slight leakage into the surrounding water, which can be detected and quantified using a conductivity meter. If the cell membrane is ruptured or the transmembrane protein pumps impaired, the cell contents leak at a greater rate. Indeed, levels of damage to plant tissue caused by drought have been investigated using electrolyte leakage (Martin et al. 1987; McKay 1992). In all cases, PBZ-treated plants maintained a lower degree of electrolyte leakage, i.e., higher degree of membrane integrity, than the respective controls at the cessation of 3 weeks of droughts.

In addition to reduced damage at the cessation of 3 weeks of drought, recovery rates of PBZ-treated plants ranged from $20 \%$ to $50 \%$ higher than non-PBZ-treated trees. Few investigations have recorded the potential of PBZ to aid in the recovery of urban trees from drought damage. Indeed, most physiological parameters recorded in this investigation as measures of tree vitality (PI, leaf necrosis, leaf chlorophyll content, electrolyte leakage) were comparable with original levels at day 0 by week 4 to 6 postrecovery indicating regeneration and full functioning of the leaf photosynthetic structure and chlorophyll molecule. Gilley and Fletcher (1997) observed that almost no decrease in chlorophyll concentration in wheat treated with PBZ compared with a loss of $28 \%$ of total chlorophyll after $3 \mathrm{hr}$ at $50^{\circ} \mathrm{C}\left(122^{\circ} \mathrm{F}\right)$ heat stress in the non-PBZ-treated plants. Recently, in a study by Still and Pill (2004) they showed that 'Marglobe' tomato plants treated with PBZ either by soaked seeds or sprayed plants have more stress tolerance compared with nontreated plants. They also reported that treated 'Marglobe' tomato plants had lower loss of total chlorophyll during the 10-day poststress recovery period compared with nontreated controls. The importance of rapid recovery from stress has been shown elsewhere. Genotypes that rebound to original or near original physiological levels most likely survive and tolerate drought episodes compared with those that do not or are slower to recover (Aguilera et al. 1997; Bauerle and Dudley 2003). In all cases, control trees (non-PBZ-treated) had the least capacity for recovery in which PI, leaf necrosis, leaf chlorophyll content, and electrolyte leakage were still $15 \%$ to $25 \%$ lower at the cessation of the experiment than original basal levels recorded at day 0 .

Overregulation of growth as manifest by stunted crinkled foliage is a major disadvantage when using growth inhibitors such as PBZ. In many cases, overregulatory effects on growth can last 2 to 3 years. In this experiment, three of the four treatments, although increasing the drought tolerance and recovery of both English and evergreen oak, resulted in a statistically significantly smaller trees in terms of height and mean leaf size. Such an effect is undesirable when planting trees into amenity environments where aesthetics are a major factor regarding tree selection.

In conclusion, water stress after planting is generally recognized as a major factor resulting in death of newly transplanted trees (Gilbertson and Bradshaw 1990). Results of this investigation indicate applications of the growth inhibitor PBZ either as a foliar spray or root drench induce a suite of physiological adaptations that confer a high degree of drought tolerance and aid in the recovery from drought-induced damage. It is suggested that PBZ-induced protection of both English and evergreen oak from damage caused by drought stress is mediated by increased antioxidant enzyme and pigment activities.

\section{LITERATURE CITED}

Aguilera, C., C.M. Stirling, and S.P. Long. 1997. Genotypic variation within Zea mays for susceptibility to and rate of recovery from chill-induced photoinhibition of photosynthesis. Physiologia Plantarum 106:429-436.

Ain-Lhout, F., M. Zunzunegui, M.C. Diaz Barradas, R. Tirado, A. Clavijo, and F. Garcia Novo. 2001. Comparison of proline accumulation in two Mediterranean shrubs subjected to natural and experimental water deficit. Plant and Soil 230:175-183.

Anon. 1984. Paclobutrazol Plant Growth Regulator for Fruit. I.C.I. Technical Data Sheet.

Apel, K., and H. Hirt. 2004. Reactive oxygen species: Metabolism, oxidative stress, and signal transduction. Annual Review of Plant Biology 55:373-399.

Asare-Boamah, N.K., G. Hofstra, R.A. Fletcher, and E.B. Dumbroff. 1986. Triadimefon protect bean plants from water stress through its effect on abscisic acid. Plant \& Cell Physiology 27:383-390.

Bañón, S., A. González, E.A. Cano, J.A. Franco, and J.A. Fernández. 2002. Growth, development and colour response of potted Dianthus caryophyllus cv Mondriaan to paclobutrazol treatment. Scientia Horticulturae 94: 371-377.

Bauerle, W.L., and J.B. Dudley. 2003. Genotypic variability in photosynthesis, water use, and light absorption among red and freeman maple cultivars in response to drought stress. Journal of the American Society of Horticultural Science 128:337-342.

Cameron, R.W.F., and G.R. Dixon. 1997. Air temperature, humidity and rooting volume affecting freezing injury to Rhododendron and other perennials. The Journal of Horticultural Science \& Biotechnology 72:553-562. 
Clark, A.J., W. Landolt, J. Bucher, and R.J. Strasser. 1998. The response of Fagus sylvatica to elevated $\mathrm{CO}_{2}$ and ozone probed by the JIP-test based on the chlorophyll fluorescence rise: OJIP, pp. 283-286. In J.L. De Kok and I. Stulen (Eds.). Responses of Plant Metabolism to Air Pollution and Global Change. Brackhuys Publishers, Leiden, The Netherlands.

- 2000. Beech (Fagus sylvatica L.) response to ozone exposure assessed with a chlorophyll a fluorescence performance index. Environmental Pollution (Barking, Essex: 1987) 109:501-507.

Craul, P.J. 1994. Soil compaction on heavily used sites. Journal of Arboriculture 20:69-74.

Dalziel, J., and D.K. Lawrence. 1984. Biochemical and biological effects of kaurene oxidase inhibitors, such as paclobutrazol, pp. 43-47. In R.G. Menhenett and D.K. Lawrence (Eds.). Biochemical Aspects of Synthetic and Naturally Occurring Plant Growth Regulators. British Plant Growth Regulator Group, Monograph No. 11, Wantage, UK.

Davis, T.D., N. Sankhla, R.H. Walser, and A. Upadhyaya. 1985. Promotion of adventitious root formation on cuttings by paclobtrazol. HortScience 20:883-884.

Davis, T.D., G.L. Steffens, and N. Sankhla. 1988. Triazole plant growth regulators. Horticultural Reviews 10: 63-105.

De Ronde, J.A., A. Van Der Mescht, and H.S.F. Steyn. 2000. Proline accumulation in response to drought and heat stress in cotton. African Crop Science Journal 8:85-92.

Ehmedov, V., M. Akbulut, and S.T. Sadiqov. 2002. Role of $\mathrm{Ca}^{2+}$ in drought stress signaling in wheat seedlings. Biochemistry 67:491-497.

Fernandez, J.A., L. Balenzategui, S. Banon, and J.A. Franco. 2006. Induction of drought tolerance by paclobutrazol and irrigation deficit in Phillyrea angustifolia during the nursery period. Scientia Horticulturae 107:277-283.

Fletcher, R.A., A. Gilley, N. Sankhla, and T.D. Davis. 2000. Triazoles as plant growth regulators and stress protectants. Horticultural Reviews 24:55-138.

Fletcher, R.A., G. Hofstra, and J. Gao. 1986. Comparative fungitoxic and plant growth regulating properties of triazole derivatives. Plant \& Cell Physiology 27:367-371.

Gilbertson, P., and A.D. Bradshaw. 1990. The survival of newly planted trees in inner cities. Arboricultural Journal 14:287-309.

Gilley, A., and R.A. Fletcher. 1997. Relative efficacy of paclobutrazol, propiconazole and tetraconazole as stress protectants in wheat seedlings. Journal of Plant Growth Regulation 21:169-175.

Jiang, Y., and B. Huang. 2001. Osmotic adjustment and root growth associated with drought preconditioning-enhanced heat tolerance in Kentucky bluegrass. Crop Science 41: $1168-1173$.
Kraus, T.E., and R.A. Fletcher. 1994. Paclobutrazol protects wheat seedlings from heat and paraquat injury. Is detoxification of active oxygen involved? Plant \& Cell Physiology 35:45-52.

Lawlor, D.W. 2001. Photosynthesis, 3rd Ed. Scientific Publishers Limited, Oxford, UK.

Levene, H. 1960. Robust tests for equality of variances. In I. Olkin, S.G. Ghurye, W. Hoeffding, W.G. Madow, and H.B. Mann (Eds.). Contributions to Probability and Statistics. Stanford University Press, Stanford, CA.

Lichtenthaler, H.K., S. Burkart, C. Schindler, and F. Stober. 1992. Changes in photosynthetic pigments and in vivo chlorophyll fluorescence parameters under photoinhibitory growth conditions. Photosynthetica 27:343-353.

Lichtenthaler, H.K., and A.R. Wellburn. 1983. Determinations of total carotenoids and chlorophylls a and b of leaf extracts in different solvents. Biochemical Society Transmycological 11:591-593.

Marshall, J.G., R.G. Rutledge, E. Blumwald, and E.B. Dumbroff. 2000. Reduction in turgid water volume in jack pine, white spruce and black spruce in response to drought and paclobutrazol. Tree Physiology 20:701-707.

Martin, U., S.G. Pallardy, and Z.A. Bahari. 1987. Dehydration tolerance of leaf tissues of six woody angiosperm species. Physiologia Plantarum 69:182-186.

McKay, H. 1992. Electrolyte leakage from fine roots of conifer seedlings: A rapid index of plant vitality following cold storage. Canadian Journal of Forestry Research 22: 1371-1377.

Mooney, H.A. 1982. Habitat, plant form, and plant water relations in Mediterranean-climate regions. Ecology Mediterranea 8:481-488.

Percival, G.C., and G.A. Fraser. 2001. Measurement of the salinity and freezing tolerance of Crataegus genotypes using chlorophyll fluorescence. Journal of Arboriculture 27:233-245.

Percival, G.C., I.P. Keary, and A.-H. Sulaiman. 2006. An assessment of the drought tolerance of Fraxinus genotypes for urban landscape plantings. Urban Forestry and Urban Greening 5:17-27.

Pinhero, R., and R. Fletcher. 1994. Paclobutrazol and ancymidol protect corn seedlings from high and low temperature stress. Plant Growth Regulation 15:47-53.

Sankhla, N., A. Upadhyaya, T.D. Davis, and D. Sankhla. 1992. Hydrogen peroxide scavenging enzymes and antioxidants in Echinochloa frumentacea as affected by triazole growth regulators. Plant Growth Regulation 11: 441-442.

Santarius, K.A. 1992. Freezing of isolated thylakoid membranes in complex media. VIII. Differential cryoprotec- 
tion by sucrose, proline and glycerol. Physiologia Plantarum 84:87-93.

Schindler, C., and H.K. Lichtenthaler. 1994. Is there a correlation between light-induced zeaxanthin accumulation and quenching of variable chlorophyll a fluorescence? Plant Physiology and Biochemistry 32:813-823.

Songstad, D.D., D.R. Duncan, and J.M. Widholm. 1990. Proline and polyamine involvement in chilling tolerance of maize suspension cultures. Journal of Experimental Botany 41:289-294.

Still, J.R., and W.G. Pill. 2004. Growth and stress tolerance of tomato seedlings (Lycopersicon esculentum Mill.) in response to seed treatment with paclobtrazol. The Journal of Horticultural Science \& Biotechnology 79:197-203.

Van Swaaij, E.J., and W.J. Feenstra. 1985. Effect of cold hardening, wilting and exogenously applied proline on leaf proline content and frost tolerance of several genotypes of Solanum. Physiologia Plantarum 64:230-236.

Von Caemmerer, S., and G.D. Farquhar. 1981. Some relationships between the biochemistry of photosynthesis and the gas exchange of leaves. Planta 153:376-387.

Watson, G.W. 2001. Soil applied paclobutrazol affects root growth, shoot growth and water potential of American elm seedlings. Journal of Environmental Horticulture 19: 119-122.

Watson, W. 1996. Tree root system enhancement with paclobutrazol. Journal of Arboriculture 22:211-217.

Yamada, M., H. Morishita, K. Urano, N. Shiozaki, K. Yamaguchi-Shinozaki, K. Shinozaki, and Y. Yoshiba. 2005. Effects of free proline accumulation in petunias under drought stress. Journal of Experimental Botany 56: 1971-1985.

Glynn C. Percival (corresponding author)

Plant Physiologist/Technical Support Specialist

R.A. Bartlett Tree Research Laboratory

The University of Reading

2 Earley Gate, Whiteknights

Reading, RG6 6AU, UK

gpercival@bartlettuk.com

Ali Mohammed Salim AlBalushi

Research Assistant and MSc Candidate

School of Biological Sciences

The University of Reading, Whiteknights

Reading, RG6 6AU, UK

Résumé. L'influence du paclobutrazol par vaporisation foliaire et par mouillage du sol a été étudiée chez des chênes anglais et des chênes toujours-verts en pot en regard de la tolérance à la sécheresse et de la reprise suite à une sécheresse. Le traitement au paclobutrazol a induit une suite d'adaptations physiologiques qui pourraient permettre à ces deux espèces de tolérer la sécheresse. Plus spécifiquement, cela a accrû le contenu foliaire total en caroténoïdes (lutéine: $\beta$-carotène:néoxanthine: $\alpha$-carotène), en xanthophylles (zeaxanthine:antheraxanthine:violaxanthine), en chlorophylle, en proline, en superoxide dismutase et en catalase. De plus, le paclobutrazol a renforcé l'intégrité de la membrane, a accrû l'efficacité de la photosynthèse foliaire et la fixation induite par la lumière du $\mathrm{CO}_{2}$ préalablement ainsi qu'à la fin du traitement de sécheresse. En dépit de l'espèce, le taux de reprise des arbres ayant subi une sécheresse était de 20 à 50\% plus élevé pour ceux traités avec le paclobutrazol que ceux non traités. Dans tous les cas, les arbres témoins (ceux non traités au paclobutrazol) avaient la plus faible capacité de recouvrement. L'application de certains traitements au paclobutrazol a induit au delà de la normale la formation de nouvelles feuilles. Les résultats de cette étude indiquent que les applications du régulateur de croissance paclobutrazol, que ce soit par vaporisation foliaire ou par mouillage sur le sol, induisent une suite d'adaptations physiologiques qui confèrent un degré utile de tolérance à la sécheresse et qui aident le recouvrement des arbres suite à des dommages par la sécheresse. Il est suggéré que la protection induite par le paclobutrazol contre les dommages par la sécheresse chez le chêne anglais et le chêne toujours-vert se fait via un accroissement de l'activité des enzymes antioxydants et des pigments.

Zusammenfassung. Hier wurde der Einfluß von Paclobutrazol (PBZ), als Blattspray und Wurzelbehandlung aufgetragen, bei trockenheits-toleranten und sich von Trockenheit erholenden, getopften Englischen und Immergrünen Eichen untersucht. Die Paclobutrazol führte zu einer Folge von physiologischen Anpassungen, die beiden Spezies ermöglichen würde, die Trockenheit zu überstehen. Genauer gesagt: gestiegener totaler Anteil von Carotinoiden und Xanthophyll im Blatt, Chlorophyll, Prolin, superoxyde Dismutase und Katalase. Zusätzlich stärkte PBZ die Blattmembranintegrität, verstärkte die Blattphotosynthese-Effizienz (PI) und die licht-induzierte CO2Fixation vor und am Ende der Trockenheitsbehandlung. Unabhängig von der Spezies lagen die Erholungsraten der trockenheitsgestressten Bäume nach der PBZ-Behandlungum 20-50\% höher als bei den unbehandelten Bäumen. In allen Fällen hatten die Kontrollbäume die schlechtesten Erholungschancen. Die Applikation bei einigen PBZ-Behandlungen führte zu einer Überregulierung bei den neuen Blattaustrieben. Die Resultate dieser Untersuchung zeigen, dass eine Applikation des Wachstumshemmers PBZ entweder als Blattspray oder als Wurzelbehandlung in der Folge zu physiologischen Anpassungen führt, die einen nützlichen Grad an Trockenheitstoleranz gewährt und hilft bei der Erholung nach Trockenheitsschäden. Wir unterstellen, dass der durch PBZ herbei geführte Schutz von Englischen und Immergrünen Eichen begleitet wird durch erhöhte Anitoxidatien-Rate und Pigment-Aktivität.

Resumen. Se investigó la influencia de paclobutrazol (PBZ), aplicado como spray foliar y al suelo, sobre la tolerancia y recuperación a la sequía de dos especies de encinos en contenedor. El tratamiento con PBZ indujo un paquete de adaptaciones fisiológicas que permitiría la tolerancia a la sequía de las dos especies. Más específicamente incrementaron el contenido total en la hoja de carotenoides (lutein: $\beta$-carotene:neoxanthin: $\alpha$-carotene) y xanthophylls (zeaxanthin:antheraxanthin:violaxanthin), chlorophylls, proline, superoxide 
dismutase y catalase. Además PBZ fortaleció la integridad de la membrana foliar, incrementó la eficiencia fotosintética (PI) e indujo la fijación de $\mathrm{CO}_{2}(\mathrm{Pn})$, antes y en la cesación del tratamiento de sequía. Independiente de las especies, las tasas de recuperación de los árboles a la sequía tratados con PBZ fueron 20 - 50\% más altas que los árboles no tratados. En todos los casos los árboles de control (no tratados con PBZ) tuvieron menor capacidad de recuperación. La aplicación de algunos tratamiento con PBZ indujo la sobre regu- lación de hojas recién emergidas. Los resultados de esta investigación indican que las aplicaciones del inhibidor del crecimiento PBZ, bien sea como spray foliar a al suelo, inducen un serie de adaptaciones fisiológicas que confieren un grado útil de tolerancia a la sequía y ayudan en la recuperación de los daños por la misma. Se sugiere que el PBZ indujo la protección de los encinos del daño causado por el estrés de la sequía y es mediado por el incremento de las actividades de enzimas y pigmentos antioxidantes. 